\title{
TERT Promoter Mutation
}

National Cancer Institute

\section{Source}

National Cancer Institute. TERT Promoter Mutation. NCI Thesaurus. Code C160585.

A molecular abnormality indicating mutation in the promoter region of the TERT gene. 